\title{
IAMJ
}

INTERNATIONAL

AYURVEDIC

MEDICAL JOURNAL

Review Article

ISSN: 2320-5091

Impact Factor: 6.719

\section{COMMON OCCUPATIONAL LUNG DISORDERS IN CURRENT INDIAN POPULATION AND PRINCIPLES OF AYURVEDIC MANAGEMENT}

\section{$\underline{\text { Keerthana. }}^{1}$, Zenica D'souza $^{2}$}

${ }^{1}$ P.G Scholar, Department of Kayachikitsa, Alva's Ayurveda Medical College and Hospital, Vidyagiri, D.K, Karnataka, India.

${ }^{2}$ Guide, Professor, Department of Kayachikitsa, Yenepoya Ayurveda Medical College and Hospital, Naringana, Mangaluru, Karnataka, India.

Corresponding Author: keerthiayush94@gmail.com

https://doi.org/10.46607/iamj2609092021

(Published Online: September 2021)

Open Access

(C) International Ayurvedic Medical Journal, India 2021

Article Received: 11/08//2021 - Peer Reviewed: 30/08/2021 - Accepted for Publication: 31/08/2021

\section{Check for updates}

\begin{abstract}
Occupational lung diseases are caused primarily as a result of exposure to risk factors arising from the work environment. Persons with few weeks of exposure to workplace hazards may experience mild symptoms, whereas long term exposure results in a complicated presentation like severe respiratory debilitation and even death. Occupational lung diseases may be misdiagnosed as COPD or other diseases, which leads to delay in the identification of the etiological factors. There is no treatment for any of the occupational lung diseases that can reverse the damage already done. So, prevention of occupational exposure is the primary strategy in these ailments. In the present era, people are turning towards Ayurveda for chronic disease management, so a long-term approach to these could be beneficial in the management of occupational lung diseases. So, it's the need of the hour for an Ayurvedic physician to be accustomed to occupational diseases and their management through Ayurveda.
\end{abstract}

Keywords: Occupational lung disorders, Ayurveda for OLD, Yoga and Pranayama. 


\section{INTRODUCTION}

Occupational diseases are caused primarily as a result of exposure to risk factors arising from the work environment. In the last few decades, rapid industrial growth has resulted in an increased incidence of occupational diseases ${ }^{1}$. It is also estimated that in India 17 million occupational non - fatal injuries and 45,000 fatal injuries occur each year. Noise, dust, fumes, toxic substances, radiation etc., are workplace health hazards that can cause occupational disease. National Institute of Occupational Safety \& Health (NIOSH) has developed a priority list of 10 leading work-related illnesses and injuries in India ${ }^{2}$. Occupational lung disease is first and occupational cancer is the second leading occupational disease on the list. In the tenth fiveyear plan (2002 - 2007), it has been recommended by the Planning commission, Government of India, that occupational and environmental health should be given priority. Negligence in occupational safety of the workers may result in a burden to the economy and the ill health of the workers results in reduced output along with large expenditure to meet the medical expenses for sickness treatment and compensation. Meanwhile, it is a fact that most occupational diseases are incurable and therefore, the best way to deal with them is their prevention. According to Ayurveda, the prime objectives is "Swasthasyaswasthyarakshana and Aturasya vikara prashamana", so Ayurveda can be utilized in occupational health both in the prevention of disease by providing good immunity and treating it with proper medications. Acharya Charaka also explained Nidana - parivarjana (Avoidance of etiological factors) as an essential component in the management of Shwasa Roga.

\section{COAL WORKER'S PNEUMOCONIOSIS ${ }^{3}$ : CWP} is also known as Black lung disease. It is common in coal miners. Anthracosis: Milder form of the disease, Asymptomatic, Carbon Pigment accumulates without a perceptible cellular reaction. Cause: It results from prolonged inhalation and deposition of coal dust. Types of CWP: According to the severity of the lung scaring it is classified into Simple CWP (12 yrs. of work exposure) and Complicated CWP. Pathogenesis: Coal dust that enters the lungs can neither be destroyed nor removed by the body. The particles are engulfed by resident alveolar or interstitial macrophages and remain in the lungs. Coal dust provides a stimulus for the macrophage to release enzymes, cytokines, oxygen radicals and fibroblast growth factors which are important in the inflammation and fibrosis of CWP. Clinical picture: Simple CWP - Chronic cough, shortness of breath on exertion, Little ventilatory impairment and in Complicated CWP - Tightness in the chest, Dyspnoea, Chronic Cough with black sputum, Pulmonary dysfunction, Cyanosis, Progressive massive fibrosis. Diagnosis: Detailed history, Chest $\mathrm{X}$-ray, CT scan, pulmonary function tests, CBC count and sputum culture, Bronchoscopy with a lung biopsy. Management: Irreversible and no specific treatment other than palliative methods. Prevention: Timely removal from further exposure, should wear a mask at the workplace, Chest radiographs are serially monitored and Smoking cessation.

ASBESTOSIS ${ }^{4}$ : Is progressive diffuse lung fibrosis. It is most often seen with those who work with asbestos or asbestos-containing products. Asbestosis occurs in about $3 \%$ of asbestos miners in India. Once initiated, lung fibrosis progresses irrespective of removal from exposure. Asbestosis increases the risk of the development of lung cancer. Cause: It is caused by inhalation and prolonged exposure to asbestos fibres. Pathogenesis: Asbestos fibres on inhalation make their way into the lungs, gets deposited in the alveoli, as fibres are insoluble, this dust deposited in the lungs causes scarring or pulmonary fibrosis leading to respiratory insufficiency, $\mathrm{Ca}$ of the bronchus, mesothelioma of the pleura or peritoneum and death. Clinical Features: Do not appear quickly and it takes 5 to 10 years of exposure to manifest. Frequent Dyspnoea, Basal crepitations, clubbing of fingers, Cardiac distress, Cyanosis, Sputum shows asbestos fibres coated with fibrin. Diagnosis: Chest X-ray: Findings appear as pleural thickening. Management: No cure as it is an irreversible condition, Steroids are given to treat the inflammation and in severe cases, a Lung transplant is suggested. Prevention: Regular check-ups and removal from further exposure. 
SILICOSIS 5 : This is a fibrotic disease of the lungs. The case was first reported in India at Kolar Gold Mines - Mysore in 1947. Cause: It is caused by inhalation and deposition of dust containing free crystalline silica. Clinically significant exposures can occur during mining, quarrying, tunnelling of granite or rock with high quartz content, sandblasting, pottery making and brickworks. Pathogenesis: After inhalation of the particles, it interacts with the epithelial cell and is ingested by macrophages which cause the activation and release of mediators inducing inflammation, fluid accumulation and tissue fibrosis. Types of Silicosis: Chronic silicosis - After 10 or more years of exposure, Accelerated silicosis - After 5 to 10 years of exposure, Acute silicosis - After weeks or months of exposure. Clinical Features: Irritant Cough, Dyspnoea on exertion, pain in the chest, with continued exposure and disease progression, lung nodules coalesce to form larger masses followed by fibrosis and bullae formation. This phase is termed progressive massive fibrosis and is associated with clinically significant lung function impairment. Silicotics are prone to pulmonary tuberculosis known as Silico - Tuberculosis. Diagnosis: Profuse small, rounded opacities predominantly in upper lung fields along with enlarged hilar and mediastinal lymph nodes, with a characteristic egg-shell calcification, are seen in a chest radiograph, Bronchoscopy, Biopsy, Sputum Test - Tuberculosis. Complications: Lung cancer, COPD, Tuberculosis (TB), Scleroderma, Chronic Bronchitis. Management: No cure, Supportive treatment: Antibiotics or anti - TB drugs (if needed), Bronchodilators, Oxygen Therapy and Mechanical ventilation. Patients with chronic silicosis may need to have a Lung Transplant. Prevention: Removal from further exposure to silica dust at the workplace is important to stop the further worsening of the disease.

BYSSINOSIS $^{6}$ : This disease is mostly reported in workers of the cotton textile industry. It is also known as Monday fever, Brown Lung Disease, Mill Fever or Cotton Worker's Lung. Cause: Inhalation of cotton fibre dust over a long period. Pathogenesis: Cotton dust may stimulate inflammation that damages the normal structure of the lung. It causes the release of histamine, which constricts the air passages. As a result, breathing becomes difficult. Over time the dust accumulates in the lung, producing a typical discolouration that gives the disease its name Brown Lung Disease. Clinical Features: Chronic cough, Progressive Dyspnea ending in Chronic bronchitis and Emphysema. Diagnosis: Detailed medical history, Pulmonary function test, Chest X-ray / CT scan. Management: Bronchodilators, Immunomodulators and Antihistamines, Corticosteroids are given only in severe cases, Oxygen therapy, Physical activity and breathing exercises. Prevention: Reduce exposure in the work environment, wear protective gear, increase ventilation, quit smoking, steaming raw cotton to reduce particle formation.

AYURVEDIC PERSPECTIVE OF OCCUPATIONAL LUNG DISEASE: -

Ayurveda has mentioned the Nidanas like Dhoomopaghata (inhalation of fumes), Rajodhooma sevana (exposure to dust and smoke), Gara visha, etc. It indicates that ancient practitioners of Ayurveda were well aware of the fact that occupation has an impact on human health ${ }^{7}$. Ayurvedic classical texts have described respiratory disorders especially under the heading of Swasa, Kasa, Rajayakshma, Pratishyaya etc. These ailments usually follow the criteria of Nidanarthakaritwa (progressive morbidity factor) i.e., the disease starts as a simple respiratory allergy like Vatika Kasa (dry cough) but may eventually end up in chronic interstitial lung disease or Kshayaja Kasa. Occupational lung diseases may be included in Shwasa and Kasa roga due to the similarity in aetiopathogenesis and clinical presentation. As per the Ayurvedic principles, respiratory diseases have the predominance of Vata dosha along with vitiation of Kapha dosha and Pranavaha srotas.

AYURVEDIC MANAGEMENT: Ayurvedic approach of management of occupational lung diseases is Nidana parivarjana and to potentiate the immune system of the individual to reduce the susceptibility towards the inhaled particles $\&$ allergens and at the same time providing symptomatic relief to the patient ${ }^{8}$. The treatment principle for respiratory disorders as per Ayurveda is to balance both vata and kapha, so the drugs used for these diseases should possess qualities 
like vata - kapha shamaka, ushna and vatanulomana. Ayurveda has potent single drugs and compound formulations for breaking the pathology of these respiratory ailments. These ayurvedic drugs possess properties like mucolytic, expectorant, bronchodilator, mast cell stabilizer and have an inhibitory action on mediators of inflammation. Shodhana procedures may also be administered as per the strength of the patient before prescribing these drugs.

SINGLE DRUGS: Scientifically proven Ayurvedic herbs used in treating respiratory diseases are: -

- Vasa: Anti - tussive, Bronchodilator, Anti - allergen.

- Shirisha: Anti-asthmatic, Anti - anaphylactic activity.

- Tulsi: Immunomodulator, Antioxidant, Anticancer activity.

- Vibhitaki: Bronchodilator, Expectorant, Antimicrobial activity.

- Bharangi: Anti-asthmatic, Antihistaminic, Mast cell stabilizer.

- Shati: Anti-asthmatic, Antioxidant, Reduces elevated eosinophilic count.

- Kantakari: Bronchodilator, Decreases oedema and secretions in the airway lumen.

- Haridra: Anti - Inflammatory, Antioxidant, Antiallergen, Anticancer activity.

- Pushkaramoola: Anti-spasmodic, Antihistaminic, Improves pulmonary function.

- Yashtimadhu: Expectorant, Antiasthmatic, Antiinflammatory, Immunostimulant.

\section{COMPOUND FORMULATIONS:}

Haridra Khanda, Shirishadi Kwatha, Kanakasava, Shirishavaleha and Rasa Manikya are found to be effective in respiratory diseases of allergic origin ${ }^{9}$. Vasa Vyaghri Kashaya, Dashamoola Katutraya Kashaya, Bharangyadi Kashaya, Talisadi Churna, Sitopaladi Churna, Shringyadi Churna, Yogarajaguggulu, Amrutaguggulu, Panchagavya Ghrita, Vasarishta, Vyaghri Haritaki, Vasavaleha, Kantakaryavaleha, Vasa Ghrita, Kantakari Ghrita, Abhraka Bhasma, Sameerapannaga Rasa, Swasa Kutara Rasa, Swasakasa Chintamani Rasa, Mahalaxmivilasa Rasa, Tribhuvana Kirti Rasa, Swasananda Gutika and Malla Sindoora are the common compound formulations used in the management of respiratory diseases since ages.

RASAYANA FORMULATIONS: Amalaki $R a$ sayana, Dashamoolaharitaki Rasayana, Agastya Haritaki, Chyavanaprasha, Vardhamana Pippali Rasayana etc. improve the defence mechanisms of lungs thereby providing resistance against various respiratory infections ${ }^{10}$.

SHODHANA PROCEDURES: Along with the above drugs, there are many shodhana therapies like Abhyanga, Swedana, Vamana, Virechana, etc. for respiratory diseases. Abhyanga with Sarsapa taila mixed with saindhava lavana over chest followed by Swedana - acts as an expectorant and relieves breathlessness ${ }^{11}$. Classical shodhana or rutu shodhana like vamana and virechana karma can be done to detoxify the body, which is exposed to dust, fumes etc in daily routine. Vamana and Virechana karma may be useful in well-built patients with kapha predominance, as studies have shown a reduction in both intensity and number of dyspnoea attacks with these therapies ${ }^{12} . \mathrm{Va}$ mana karma corrects the pathology by eliminating one of the disease causative factors i.e., Kapha from its main site of accumulation, thereby clearing the obstructed channels of vata and relieves dyspnoea.

YOGA MODALITIES: Surya namaskara, Chakrasana, Ardhachakrasana, Dhanurasana, Bhujangasana, Matsyasana, Ushtrasana. major types of coal worker's pneumoconiosis - simple and complicated (or progressive massive fibrosis).

PRANAYAMA: Pranayama is one of the eight branches of Ashtanga Yoga. The practice of pranayama regularly for a longer duration is found to be effective in managing respiratory diseases ${ }^{13}$. Pranayama leads to a marked improvement in lung functions by strengthening the respiratory muscles and decreasing the resistance to the airflow in the lungs. $\mathrm{Ka}$ palabhati, Jalaneti, Vamanadhouti is also found use$\mathrm{ful}^{14}$. Hence, Pranayama can be advised as a lung strengthening tool to manage occupational lung diseases ${ }^{15}$.

DIETARY AND LIFESTYLE MODIFICATION: Exposure to dust, Fumes, Pollutants, Cold and humid atmosphere, Smoking, Chilled water, Curd and curd 
preparations should be avoided and intake of lukewarm water is preferred.

\section{DISCUSSION}

The increased level of air pollution and its causative toxicant in environment is burning problem all over world. Ayurveda is an ancient science and causative factor (hetu) and pathogenesis (samprapti), principle of prevention and management has been well described in Ayurveda. In Ayurveda rajodhooma has been described as a causative factor of respiratory disease including shwasa, hikka, kasa and pratishyaya. All causative toxicant causes irritations and inflammations to respiratory tract (pranavaha srotas) due to it respiratory mucosa produces extra mucosal secretion. These extra mucosal secretions along with dust obstruct the air entry and causes COPD (Chronic obstructive pulmonary disease), etc. Diagnosis of environmental toxicant induces respiratory disease is based on history of frequent exposure of air toxicant, clinical manifestation like breathlessness, chronic cough with sputum and radiological hyper translucency of long field in X-ray chest. Ayurveda is based on principle of prevention and treatment of disease as prevention is better than cure, the social prevention based on community and personal prevention based on diseased person is needed to free from such type of big problem. Acharya Charaka has recommended the nidana parivarjana to break up the entry of causative factors and prevent the diseases. The patients of respiratory diseases avoid leaving or going such places where the pollution is maximum. He should use air filter mask while leaving the home. The principle of management of Ayurveda is based on Samshodhana and Samshamana chikitsa. It is need to samshodhana chikitsa best before medication. In environment toxicant induced respiratory disease the vamana karma using vamaka yoga prepared by fruit juice Lagenaria siceraria with milk should be beneficial as this is indicated for kritrima visha. Sitopaladi, Yashtimadhu and Tankana bhasma given along with honey should be useful to calm down the extra mucosal secretion of upper respiratory tract (vitiated Kapha) in case of chronic bronchitis where the vitiated kapha has been collected in lower respiratory tract, the shwasa kuthara rasa should be used with sitopaladi, yashtimadhu, tankana bhasma instead of laxmi vilasa rasa. In case of chronic allergic rhinitis and chronic allergic bronchitis both laxmivilasa rasa as well as shawasa kuthara rasa should be given along with sitopaladi, yashtimadhu and tankana bhasma. As the mahasrotas is one of the root places (moola sthan) of pranavaha srotas, the pranavaha srotas in either chronic allergic rhinitis or chronic allergic bronchitis or both should be needed to normalize it without pacify the vitiated kapha within the mahasrotas. It is difficult to give complete cures in said disease. Chitraka haritaki avaleha given with medicated milk, prepared from turmeric and zinger should be beneficial and help to normalize the vitiated annavaha srotas which the root places of pranavaha srotas. Vasa avaleha also helps to pacify the vitiated kapha of pranavaha and annavaha srotas both. Hence, it should be given in bronchitis. As environmental toxicant causes irritations and inflammations, patients who have a sensitive respiratory mucosa, need to develop more immunity to fight the irritation and inflammation of environmental toxicant to avoid recurrence of allergic respiratory disease. The Nasya therapy by shadbindu oil after given with gentle massage of warm mustard oil and local swedana by warm cotton clothes should be helpful to develop the special strength and immunity of respiratory mucosa. Thus, preventative method, Samshodhana, Samshamana chikitsa, Srotogata chikitsa and nasya therapy may give relief from environmental toxicant induces respiratory diseases.

\section{CONCLUSION}

Industrialization is a major factor for developing India, it has equal merits and demerits, though industrialization is giving job opportunities for many people in the country and contributing to increasing GDP but also causing environmental pollution and occupational hazards. The duty of the medical system is very important in developing industrial growth by providing health support to the industrial workers ${ }^{16}$. So as Ayurveda, being a life science has a role in improvising the health status of industrial workers by giving preventive and curative therapeutics. The policymakers and 
Ayurveda Vaidya community should emphasize making SOPs on the management of occupational hazards and involve them in national programs.

\section{REFERENCES}

1. K. Park, Park's Textbook of Preventive and Social Medicine, $21^{\text {st }}$ edition, Occupational Health, P: $746-$ 759.

2. https://www.osha.gov/Publications/OSHA_FS3647_Welding.pdf.

3. YP Munjal, API Textbook of Medicine, 9th edition, The Association of Physicians of India, section 23: Surendra K. Sharma, Chapter 13: Occupational and Environmental Lung Diseases - Ashutosh Nath Aggarwal, 2012, P: 1754.

4. Nicholas A. Boon, Nicki R. Colledge, Brian R. Walker, Davidson's Principles and Practice of Medicine, $20^{\text {th }}$ edition, Respiratory Disorders, P: 718 - 722.

5. Graham Douglas, Fiona Nicol, Colin Robertson, Macleod's Clinical Examination, $12^{\text {th }}$ edition, Section - 2, System Examination: The Respiratory System, P: 153.

6. Kasper Hauser, Braunwald Longo, Fauci Jameson, Harrison's Principles of Internal Medicine, Vol - 1, Section - 2, Diseases of the Respiratory System: Environmental Lung Diseases, P: 1521.

7. Vaidya Jadavji Trikamji Acharya, Charakasamhita (sutra sthana 30/26) Varanasi; Choukhamba Surabharati Prakashan,2009, P: 187.

8. Vaidya Jadavji Trikamji Acharya, Charakasamhita (chikitsa sthana 17/11) Varanasi; Choukhamba Surabharati Prakashan,2009, P: 533.

9. Pt. Hari Sadashiva Shastri, Ashtanga Hridaya (Uttaratantra 18/26) Varanasi; Choukhamba Surabharati Prakashana,2010, P: 839.

10. Pt. HariSadashiva Shastri, Ashtanghridaya (Uttaratantra 18/26) Varanasi; Choukhmba Surabharati Prakashan;2010 p 839 9. Prof K R Shrikanthamurthy, Sharangadhara samhita, Varanasi, choukhmbaorientalia. P 173

11. Pt. Hari Sadashiva Shastri, Ashtanghridaya (Uttaratantra 16/28) Varanasi; Choukhmba Surabharati Prakashan;2010 p 832 11. Minton, J. (1946). Occupational Eye Diseases. British Medical Journal, 1(4440), 211-212.

12. Pt. HariSadashivaShastri, Ashtanghridaya (Uttaratantra 18/33) Varanasi; Choukhmba Surabharati Prakashan;2010 p 839 13. Meghwaniand Deshmukh; Ayurvedic approach on computer vision syndrome;
International Journal of Ayurveda and pharmaceutical Chemistry, Vol. 4 Issue 2 2016; 298-304.

13. Kaviraj Ambikadutta Shastri, editor. Sushruta Samhita with Ayurveda Tattva Sandipika.Varanasi: Chaukhamba Sanskritsamsthana; Reprint; 2006. p.118.

14. Kaviraj Ambikadutta Shastri, editor. Sushruta Samhita with Ayurveda Tattva Sandipika.Varanasi: Chaukhamba Sanskritsamsthana; Reprint; 2006. p.119.

15. Kaviraj Ambikadutta Shastri, editor. Sushruta Samhita with Ayurveda Tattva Sandipika.Varanasi: Chaukhamba Sanskritsamsthana; Reprint; 2006. p.120-121.

16. https://www.osha.gov/dte/library/industrial_hygiene/i ndustrial_hygiene.html

\section{Source of Support: Nil Conflict of Interest: None Declared}

How to cite this URL: Keerthana. S \& Zenica D'souza: Common Occupational Lung Disorders In Current Indian Population And Principles Of Ayurvedic Management. International Ayurvedic Medical Journal \{online\} 2021 \{cited September 2021\} Available from: http://www.iamj.in/posts/images/upload/2093_2098.pdf 